\title{
NECESSIDADE DA EXECUÇÃO PENAL APÓS O JULGAMENTO EM SEGUNDA \\ INSTÂNCIA
}

\author{
NEED FOR CRIMINAL EXECUTION AFTER THE SECOND INSTANCE \\ JUDGMENT
}

\author{
Lucas Gonçalves Da Silva ${ }^{1}$ \\ Matheus Nogas ${ }^{2}$
}

\section{RESUMO}

Trata-se de trabalho que desenvolve a necessidade do posicionamento tradicional do Supremo Tribunal Federal, possibilitando a execução da pena, logo após a condenação em segundo grau. Uma vez que, após a condenação por órgão colegiado, todo o arcabouço fático daquele determinado processo fora encerrado. Não podendo-se, portanto, postergar a impunidade do réu. Debate-se os argumentos utilizados por parcela da doutrina, que através de uma leitura simplista e equivocada da Constituição da República, utilizando equivocadamente o princípio da presunção de inocência para garantir a prorrogação da impunidade.

Palavras-chave: prisão em segunda instância; execução da pena; possibilidade de execução da pena logo após condenação em segundo grau.

\begin{abstract}
It is a work that develops the need for the traditional positioning of the Supreme Court, enabling the execution of the sentence, right after the second degree conviction. Once, after the conviction by a collegiate body, the entire framework of that particular case had been terminated. It cannot therefore be postponed the impunity of the defendant. The arguments used by a portion of the doctrine are debated, which through a simplistic and mistaken reading of the Constitution of the Republic, mistakenly using the principle of the presumption of innocence to ensure the extension of impunity.

keywords: arrest in second instance; execution of the sentence; possibility of execution of the sentence soon after second-degree conviction.

\footnotetext{
${ }^{1}$ Pós-doutor em Direito pela Università Degli Studi G. dAnnunzio (Italia) e pela Universidade Federal da Bahia. Doutor e Mestre em Direito do Estado, na sub-área de Direito Constitucional, pela Pontifícia Universidade Católica de São Paulo-PUC/SP. Professor Associado da Graduação em Direito e do Programa de Mestrado em Direito na Universidade Federal de Sergipe-UFS. Consultor da Câmara de Assessoramento da FAPITEC/SE. Consultor da Coordenação de Aperfeiçoamento de Pessoal de Nível Superior - Capes. Vice-Presidente do Conselho Nacional de Pesquisa e Pós-graduação em Direito - CONPEDI.

${ }^{2}$ Mestrando em Direito Empresarial e Cidadania pelo Centro Universitário Curitiba - UNICURITIBA.
} 


\section{INTRODUÇÃO}

As frequentes alterações no entendimento da mais alta corte de justiça de nosso país no que se refere a prisão em segunda instância têm suscitado debates interessantes. Em um horizonte calcado pela instabilidade, onde o mesmo tribunal alterou o entendimento que vigorava até 2009 de possibilidade da prisão logo após a condenação em segundo grau, para a impossibilidade.

Esse entendimento vigorou até o ano de 2016, alterando-se novamente pela possibilidade de execução da pena. E recentemente, no ano de 2019, o supremo alterou novamente seu posicionamento, corroborando a ideia de que não trata-se de uma interpretação unívoca do texto legal.

Por quatro vezes alteraram o entendimento jurisprudência em razão do amplo entendimento do disposto no texto constitucional.

Assim trata-se na verdade, de um amadurecimento de ideias, analisar o texto normativo além da literalidade, em apreço a máxima eficácia constitucional.

Na contramão da tutela dos direitos e garantias fundamentais, parcela da doutrina de forma rasa defende a proibição da execução da pena antes do trânsito em julgado. Muitas vezes alegando a inconstitucionalidade de tal medida. Em uma temática curiosa, onde pretende-se utilizar a constituição para ferir a constitucional.

Uma das formas que se tem encontrado para desqualificar o debate e os defensores da prisão logo após a condenação pelo órgão colegiado, seria de que esta tese somente existe única e exclusivamente para agradar a opinião pública, de modo que estaria calcada por um “populismo judicial”.

Não raras vezes também utilizam falsos dados, ou dados de instituições parciais, sem considerar os dados oficiais, como na afirmação ilusória de que a possibilidade de execução da pena nesses casos, agravaria o sistema prisional brasileiro, tendo em vista o encarceramento massivo que ocorreria.

A questão é amplamente debatida e deve ser discutida nesse caso com a análise de dados, que comprovam justamente o contrário, vencendo os raros argumentos de que a prisão em segunda instância somente agravaria o encarceramento.

Não poucas vezes, supervalorizam os direitos fundamentais dos acusados, olvidando dos próprios direitos fundamentais ou dos demais cidadãos que não optaram pela criminalidade.

Nessa perspectiva, tão fundamental como a presunção de inocência, é a justiça. Pois 
sem ela não poderemos aferir e potencializar a própria presunção de inocência, ou pior, estaríamos sentenciados a voltar o status quo de punitivismo descomedido das sociedades primitivas.

Se uma sociedade não possui um sistema judicial efetivo, escancara a ineficiência do Estado para tutela de direitos e garantias dos que não cometeram delitos, causando insegurança nos demais cidadãos, e nos casos mais graves, recorrem a realizar "justiça com as próprias mãos".

Não pode-se permitir que esses que se dizem defender a Constituição da República, realizando uma leitura torta da mesma, viole diversas vezes o texto constitucional, deturpando uma série de direitos, como o direito a celeridade processual, duração razoável do processo, e os direitos fundamentais das vítimas e de todos que compõe o tecido social.

Sem considerar a frontal violação a ordem pública, prevista no art. 312 do Código de Processo Penal. Como definiu o Ministro Luis Roberto Barroso em seu voto, permitir que o réu em primeira e segunda instância, a possibilidade de ficar solto três ou cinco anos, levando uma vida normal, muitas vezes utilizando os valores que subtraiu, é uma negação de justiça, pois não há mais dúvidas sobre autoria ou materialidade

Trata-se de uma questão de justiça, não de opinião pública. Um dos índices de distinção das sociedades civilizadas das sociedades punitivas com baixo grau de civilização é a presença de justiça no tecido social.

Em uma sociedade democrática, os valores como justiça, cidadania e civilidade formam um arcabouço estamental digno, que retira o homem das mazelas de um estado selvagem, ou um Estado de Natureza. 


\section{NECESSIDADE DA EXECUÇÃo DA PENA APÓS A CONDENAÇÃO EM SEGUNDO GRAU}

O Supremo Tribunal Federal recentemente alterou mais uma vez seu entendimento no que se refere a prisão em segunda instância. Debateu o princípio da presunção de inocência, inscrito no art. 5, inciso LVII da Constituição da República, entendendo pela não possibilidade de execução da pena após o segundo grau de jurisdição.

O dispositivo constitucional diz que "ninguém será considerado culpado até o trânsito em julgado de sentença penal condenatória”. Assim, não deve ser feita uma simples análise literal do texto, e ainda que o fizesse não teria como a impossibilidade de prisão logo após o segundo grau prosperar, como será observado adiante. Deve-se realizar uma leitura do dispositivo constitucional, de forma relacionada ao disposto na Lei de Introdução às Normas do Direito Brasileiro, o Decreto-Lei n. 4.6571942.

Deve maximizar a potencialidade da exegese normativa, pois o artigo $5^{\circ}$ da referida lei procura a potencialização desse ideário, oferecendo uma diretriz clara do modo como o juiz deve interpretar os dispositivos: "Na aplicação da lei, o juiz atenderá aos fins sociais a que ela se dirige e às exigências do bem comum".

Antes de adentrarmos na questão prisão e liberdade, devemos relembrar a decisão tomada pelo pleno do Supremo Tribunal Federal, no Habeas Corpus 126.292 que foi julgado no dia 17 de fevereiro de 2016. Entendeu o Supremo Tribunal Federal através da maioria de seis a cinco (vencidos Rosa Weber, Celso de Mello, Marco Aurélio, Dias Toffoli e Ricardo Lewandowski), que sobrevindo a condenação criminal em segundo grau, quer porque confirmada a sentença penal condenatória, quer porque prolatada a condenação em segundo grau, impositiva de uma pena privativa de liberdade, já caberia a execução provisória.

E porque caberia a execução provisória?

Porque nós devemos potencializar o art. $5^{\circ}$ inciso 57 da Constituição da República no que diz que ninguém será considerado culpado de crime antes do trânsito em julgado de uma sentença penal condenatória, com uma leitura não literal mas sim propositalmente ampla englobando o disposto no artigo $5^{\circ}$ da Lei de Introdução às Normas do Direito Brasileiro. De modo que não podemos tratar a presunção de inocência de qualquer cidadão que nunca praticou qualquer delito, com a mesma carga de um sujeito que fora investigado, processado e condenado em primeira e segunda instância.

Ponderou o Supremo Tribunal Federal que ante o julgamento em segundo grau, restaria a defesa o recurso especial ao Supremo Tribunal Federal e recurso extraordinário ao 
Supremo Tribunal Federal.

Recursos que não admitem reexame fático, não admitem um reexame probatório. Consequentemente o arcabouço fático daquela demanda já estaria acertado em definitivo. E, portanto, nada impediria a execução provisória da pena, pois nesse momento não poderíamos mais falar em uma presunção de inocência, nem de uma presunção de não culpabilidade, o que permitiria a execução provisória, porque não haveria mais como encarar aquele acusado como ainda presumidamente inocente.

O Ministro Luiz Fux chegou a afirmar que os fatos que restaram acertados estes já teriam transitado em julgado, até porque a jurisprudência do Supremo Tribunal Federal admite o trânsito em julgado de uma condenação em capítulos ${ }^{3}$.

Foi se além, e afirmou-se a necessidade de se compatibilizar a presunção de inocência ou de não culpabilidade com a própria efetividade da jurisdição penal. Porque se já tivemos aquela demanda examinada por um juízo em primeiro grau, por no mínimo três magistrados em segundo grau, todos concluindo pela condenação, pela procedência do pedido condenatório, seria um desserviço à efetividade da jurisdição penal, não admitir a execução provisória da pena.

Considerados que os recursos especial e extraordinário, se destinam a discussões jurídicas, mas não ao acertamento fático que já teria ocorrido e já teria ocorrido dentro dessa ótica de maneira definitiva.

Senão fosse aberta de possibilidade da execução provisória, simplesmente acabaríamos abrindo margem ao advento da prescrição, porque após o acórdão condenatório, o próximo marco interruptivo da prescrição é o início do cumprimento da pena, que estaria postergado até que sobreviesse o trânsito em julgado da condenação.

Então, assim entendeu o Supremo Tribunal Federal naquela ocasião, retomando uma orientação que prevaleceu anteriormente, em razão de sobrevir decisões da $2^{\mathrm{a}}$ turma do Supremo Tribunal Federal, capitaneadas pelo ministro Gilmar Mendes, que nesse julgado mudou de orientação.

A regra do art. 57 da Constituição da República, acerca desse princípio sempre se ponderou em torno da primeira parte do texto, não da segunda. Não ser considerado culpado, significaria seria ser inocente? E então teríamos presunção de inocência? Claramente inspirada na doutrina de Ferrajoli.

Ou não ser considerado culpado significaria vedar, uma antecipação apenas da culpa. A discussão sempre residiu nesse ponto. Tínhamos de um lado, a ideia de uma presunção de

\footnotetext{
${ }^{3}$ Destacou o Ministro Luiz Fux na página 58 de seu voto.
} 
inocência versus a presunção de culpabilidade, embora não raros os ministros do Supremo Tribunal Federal tenham confundido as duas expressões.

As duas expressões não são sinônimas, porque por óbvio a presunção de inocência tem um amalgama infinitamente mais significativo do que presunção de culpabilidade.

Presunção de inocência - não ser considerado culpado, significaria "ser inocente" - se pensarmos por este ângulo, que a Constituição da República daria à todos uma presunção e mais até, um estado de inocência, uma vez que utiliza o verbo ser, ninguém será considerado culpado, se não for considerado culpado é porque é inocente, se raciocinarmos por este ângulo, nós traríamos profundas dificuldades para o implemento do processo penal, para começar pelas medidas cautelares constritivas da liberdade.

Pois afinal de contas, como pensar em privar ou restringir a liberdade, uma pessoa tida pela Constituição da República como inocente. Teria essa primeira dificuldade.

Não só o Supremo Tribunal Federal, mas as cortes constitucionais europeias como um todo, encaram essa presunção de maneira mais restrita, como não culpabilidade. Não podemos antecipar a culpa expressa do acusado, porém, o status de réu criminal pode sim justificar a imposição de determinados ônus aquelas pessoas.

E isso está muito bem resolvido tanto no Supremo Tribunal Federal, como no Superior Tribunal de Justiça, exemplos:

Artigo 89 da Lei n. 9.099, uma das condições para a proposta de suspensão condicional do processo é de que o réu não esteja sendo processado por outro crime, ou seja, o status de réu criminal já seria impeditivo da suspensão condicional do processo, consectário lógico do artigo 5, inciso LVII da Constituição da República, se pensado como presunção de não culpabilidade.

Ou na Lei da Ficha Limpa, que fora expressamente mencionada no julgamento pelo Supremo Tribunal Federal, tendo um dos impeditivos à candidatura nos termos do artigo $1^{\circ}$ da Lei Complementar n. 64, modificada pela Lei Complementar n. 135, os que forem condenados em decisão transitada em julgado, ou proferida por órgão colegiado da justiça eleitoral, por corrupção eleitoral e outros crimes. Na alínea "e" do inciso I, diz: "os que forem condenados, em decisão transitada em julgado ou proferida por órgão judicial colegiado, desde a condenação até o transcurso do prazo de 8 (oito) anos após o cumprimento da pena, pelos crimes". Independentemente do trânsito em julgado, ou seja, isso significa que a condenação criminal por um órgão colegiado, daria a este réu um outro ônus, o ônus de não poder candidatar-se nas eleições.

São todos ônus inerentes a existência de um processo crime, ou condenação ainda não 
transitada em julgado. É possível conformar esse fato com uma presunção de não culpabilidade.

São questões que devem ser observadas e tratadas com seriíssimo compasso com a realidade nacional. Uma vez que a carência de aplicabilidade normativa e o simbolismo carregado pela ausência de cumprimento legal influem a ideia que o "crime compensa". E esse ideário, quando reproduzido em nosso país ou em nossa cultura, já se mostrou ser desastroso e devastador.

Criminólogos tentam transpor ideários alemães, desenvolvidos nos séculos XIX e no início do século XX, à la carte, sem se ater, que a realidade brasileira do século XXI é deveras avessa.

O Brasil não é formado por alemães ou austríacos, que embora possam surgir em períodos de recesso em férias em nosso país, não são a regra. O Brasil é um país gigantesco, de proporções continentais, e com desigualdades e diferenças culturais consideráveis.

O paulistano tem um modo de pensar e agir, completamente diferente de um caruaruense no agreste pernambucano. E ignorar essa consideração mostra um despreparo para decidir questões que envolvem o Brasil como um todo.

Uma mudança no entendimento jurisprudencial desta magnitude envolve questões muito mais complexas que passam desde o número de encarcerados, o número de prisões cautelas decretadas, além da insegurança jurídica e confiabilidade nas instituições.

Portanto, transpor ideias penais alemães, e acreditar que o modelo de conduta do cidadão alemão é o mesmo que o brasileiro, onde diante de um sistema judicial penal, fraco e inoperante, assimilaria da mesma forma que o "crime não compensa", mesmo ausente o exemplo da punição, é uma ilusão absurda.

Freud define que "uma ilusão não é a mesma coisa que um erro; tampouco é necessariamente um erro" e vai além:

\footnotetext{
"Por outro lado, foi uma ilusão de Colombo acreditar que descobriu um novo caminho marítimo para as Índias. O papel desempenhado por seu desejo nesse erro é bastante claro. Pode-se descrever como ilusão a asserção feita por certos nacionalistas de que a raça indo-germânica é a única capaz de civilização, ou a crença, que só foi destruída pela psicanálise, de que as crianças são criaturas sem sexualidade. O que é característico das ilusões é o fato de derivarem de desejos humanos. Com respeito a isso, aproximam-se dos delírios psiquiátricos, mas deles diferem também, à parte a estrutura mais complicada dos delírios.” (FREUD, 1996, p. 17)
}

Portanto, não podemos nos furtar a transpor ideais à la carte, que deram certo em outras localidades em realidades e tempo muito diferente do nosso. 
A realidade do Brasil é observada pelos dados apresentados pelo Departamento Penitenciário Nacional, que advertem a diminuição do encarceramento quando da possibilidade de prisão após a condenação em segundo grau, e desmente as alegações de parte da doutrina, de que a possibilidade aumentaria não somente a prática de novos crimes, mas aumentaria o encarceramento.

Frequentemente parte da doutrina advoga a tese de que o Brasil e o ordenamento brasileiro como um todo, deve se aproximar de países que atingiram um alto grau de desenvolvimento e alto grau de respeitabilidade de direitos fundamentais, invocando-se por diversas vezes, o Pacto de San José da Costa Rica.

Da mesma forma, não pode o Brasil, se distanciar do uníssono entendimento dos países desenvolvidos, como bem destacado o Ministro Teori Zavascki ${ }^{4}$, em seu voto no ano

\footnotetext{
${ }^{4}$ Colaciona-se referência do voto do Ministro Teori Zavascki: "Não é diferente no cenário internacional. Como observou a Ministra Ellen Gracie quando do julgamento do HC 85.886 (DJ 8 Em elaboração HC 126292 / SP 28/10/2005), "em país nenhum do mundo, depois de observado o duplo grau de jurisdição, a execução de uma condenação fica suspensa, aguardando referendo da Corte Suprema". A esse respeito, merece referência o abrangente estudo realizado por Luiza Cristina Fonseca Frischeisen, Mônica Nicida Garcia e Fábio Gusman, que reproduzo: "a) Inglaterra. Hoje a legislação que trata da liberdade durante o trâmite de recursos contra a decisão condenatória é a Seção 81 do 'supreme court act 1981'. Por esse diploma é garantido ao recorrente a liberdade mediante pagamento de fiança enquanto a Corte examina o mérito do recurso. Tal direito, contudo, não é absoluto e não é garantido em todos os casos. (...) O 'criminal justice act 2003' representou restrição substancial ao procedimento de liberdade provisória, abolindo a possibilidade de recursos à 'hight court' versando sobre o mérito da possibilidade de liberação do condenado sob fiança até o julgamento de todos os recursos, deixando a matéria quase que exclusivamente sob competência da 'crown court'. (...) Hoje, tem-se que a regra é aguardar o julgamento dos recursos já cumprindo a pena, a menos que a lei garanta a liberdade pela fiança. b) Estados Unidos. A presunção de inocência não aparece expressamente no texto constitucional americano, mas é vista como corolário da $5^{\mathrm{a}}, 6^{\mathrm{a}}$ e $14^{\mathrm{a}}$ emendas. Um exemplo da importância da garantia para os norte-americanos foi o célebre caso 'Coffin versus Estados Unidos' em 1895. Mais além, o Código de Processo Penal Americano (criminal procedure code), vigente em todos os Estados, em seu art. 16 dispõe que 'se deve presumir inocente o acusado até que o oposto seja estabelecido em um veredicto efetivo'. (...) Contudo, não é contraditório o fato de que as decisões penais condenatórias são executadas imediatamente seguindo o mandamento expresso do Código dos Estados Unidos (US 9 Em elaboração HC 126292 / SP Code). A subseção sobre os efeitos da sentença dispõe que uma decisão condenatória constitui julgamento final para todos os propósitos, com raras exceções. (...) Segundo relatório oficial da Embaixada dos Estados Unidos da América em resposta a consulta da $2^{\mathrm{a}}$ Câmara de Coordenação e Revisão do Ministério Público Federal, 'nos Estados unidos há um grande respeito pelo que se poderia comparar no sistema brasileiro com o 'juízo de primeiro grau', com cumprimento imediato das decisões proferidas pelos juízes'. Prossegue informando que 'o sistema legal norte americano não se ofende com a imediata execução da pena imposta ainda que pendente sua revisão'. c) Canadá (...) O código criminal dispõe que uma corte deve, o mais rápido possível depois que o autor do fato for considerado culpado, conduzir os procedimento para que a sentença seja imposta. Na Suprema Corte, o julgamento do caso R.v.Pearson(1992) e S.C.R. 665, consignou que a presunção da inocência não significa, é claro, a impossibilidade de prisão antes de um acusado antes que seja estabelecida a culpa além de alguma dúvida. Após a sentença de primeiro grau, a pena é automaticamente executada, tendo como exceção a possibilidade de fiança que deve preencher requisitos rígidos previstos no criminal code, válido em todo o território canadense. (...) d) Alemanha (...) Não obstante a relevância da presunção da inocência, diante de uma sentença penal condenatória, o Código de Processo Alemão (...) prevê efeito suspensivo apenas para alguns recursos. (...) Não há dúvida, porém, e o Tribunal Constitucional assim 10 Em elaboração HC 126292 / SP tem decidido, que nenhum recurso aos Tribunais Superiores tem efeito suspensivo. Os alemães entendem que eficácia (...) é uma qualidade que as decisões judiciais possuem quando nenhum controle judicial é mais permitido, exceto os recursos especiais, como o recurso extraordinário (...). As decisões eficazes, mesmo aquelas contra as quais tramitam recursos especiais, são aquelas que existem nos aspectos pessoal, objetivo e temporal com efeito de obrigação em relação às consequências jurídicas. e) França A Constituição Francesa de 1958 adotou com a carta de direitos fundamentais
} 
de 2016. Na oportunidade, o ministro destacou os países que permitem a execução da pena nesses casos: Inglaterra, Estados Unidos da América, Canadá, Alemanha, França, Portugal, Espanha, Argentina.

De modo que nenhum dos pactos e convenções assinadas pelo Brasil exigem o trânsito em julgado para a execução da pena, devendo seguir o padrão de justiça praticado em todo o mundo.

Trata-se de uma incongruência descomunal tratada pela mais alta de corte de justiça de nosso país, considerando a possibilidade de prisão preventiva (artigo 311 do Código de Processo Penal) e prisão temporária (lei n. 7.960/1989), que podem ser decretadas antes mesmo da sentença de primeiro grau. Por que proibiria a prisão depois de verificada a materialidade do crime?

A garantia constitucional da presunção de inocência é uma conquista global, e não um instituto tupiniquim. Portanto, qualquer tratativa sobre o mesmo requer maiores cautelas. É uma questão seriíssima, que não deve ser tratada como vem sendo por parte da doutrina, de que os favoráveis pela volta ao tradicional posicionamento jurisprudencial do Supremo Tribunal Federal estão acometidos e influenciados pela opinião pública, em um "populismo judicial ${ }^{5}$ ".

Não trata-se, evidentemente de agradar ou não a opinião pública como destacou o Ministro Luís Roberto Barroso em seu voto no julgamento das Ações Diretas de Constitucionalidade 43, 44 e 54. De outra sorte, quando considerarmos a volatilidade do

a Declaração dos Direitos do Homem e do Cidadão de 1789, um dos paradigmas de toda positivação de direitos fundamentais da história do mundo pós revolução francesa. (...) Apesar disso, o Código de Processo Penal Francês, que vem sendo reformado, traz no art. 465 as hipóteses em que o Tribunal pode expedir o mandado de prisão, mesmo pendente outros recursos. (...) f) Portugal O Tribunal Constitucional Português interpreta o princípio da presunção de inocência com restrições. Admite que o mandamento constitucional que garante esse direito remeteu à legislação ordinária a forma de exercê-lo. As decisões dessa mais alta corte portuguesa dispõem que tratar a presunção d inocência de forma absoluta corresponderia a impedir a execução de qualquer medida privativa de liberdade, mesmo as cautelares. g) Espanha (...) A Espanha é outro dos países em que, muito embora seja a presunção de inocência um direito constitucionalmente garantido, vigora o princípio da efetividade das decisões condenatórias. (...) Ressalte-se, ainda, que o art. 983 do código de Processo Penal Espanhol admite até mesmo a possibilidade da 11 Em elaboração HC 126292 / SP continuação da prisão daquele e que foi absolvido em instância inferior e contra o qual tramita recurso com efeito suspensivo em instância superior. h) Argentina $\mathrm{O}$ ordenamento jurídico argentino também contempla o princípio da presunção da inocência, como se extrai das disposições do art. 18 da Constituição nacional. Isso não impede, porém, que a execução penal possa ser iniciada antes do trânsito em julgado da decisão condenatória. De fato, o Código de Processo Penal federal dispõe que a pena privativa de liberdade seja cumprida de imediato, nos termos do art. 494. A execução imediata da sentença é, aliás, expressamente prevista no art. 495 do CPP, e que esclarece que essa execução só poderá ser diferida quando tiver de ser executada contra mulher grávida ou que tenha filho menor de 6 meses no momento da sentença, ou se o condenado estiver gravemente enfermo e a execução puder colocar em risco sua vida" (Garantismo Penal Integral, $3^{\mathrm{a}}$ edição, 'Execução provisória da pena. Um contraponto à decisão do STF no HC 84.078', p. 507)” - Habeas Corpus 126.292 São Paulo. Supremo Tribunal Federal, 2016, Voto Teori Zavascki.

5 Como destacou o Ministro Luís Roberto Barroso em seu voto no julgamento das Ações Diretas de 
termo "opinião pública", que altera-se conforme o caso e não se serve como fundamento para coibir a potencialização de interpretação de normas constitucionais.

Assim como os ideários de "homem bom" e o "homem justo"," podem variar de localidades em localidades, "opinião pública" pode ser facilmente utilizada como manobra ideológica nesses casos.

Trata-se, portanto, de uma questão de justiça. Ideário que deve estar presente em qualquer sociedade com grau mínimo de civilização, pois caso contrário estamos sujeitos a voltarmos ao status quo do o homem é o lobo do próprio homem.

Não pode-se tratar a presunção de inocência nossa, com a mesma carga que um sujeito, investigado, processado, condenado em primeiro grau, recorreu, condenado em segundo grau.

Em 23 de outubro de 2019, o Supremo Tribunal Federal julgou três Ações Declaratórias de Constitucionalidade que tinha como escopo o tema do princípio da presunção de inocência (ADC 43, ADC 44 e ADC 54).

O Supremo Tribunal Federal alterou recentemente o entendimento novamente, 0 artigo 283 do Código de Processo Penal, serviu de forma basilar a orquestrar esta mudança, que possuía a seguinte redação: “Artigo 283. Ninguém poderá ser preso senão em flagrante delito ou por ordem escrita e fundamentada da autoridade judiciária competente, em decorrência de sentença condenatória transitada em julgado ou, no curso da investigação ou do processo, em virtude de prisão temporária ou prisão preventiva”.

Ainda no ano de 2019 sofreu alteração na redação pela Lei n. 13.964, de 2019: “Artigo 283. Ninguém poderá ser preso senão em flagrante delito ou por ordem escrita e fundamentada da autoridade judiciária competente, em decorrência de prisão cautelar ou em virtude de condenação criminal transitada em julgado".

Não se trata de interpretação gramatical ou literal, mas sim uma pretensão ilusória, que o interprete da norma não faça diferença alguma, sendo única e exclusivamente um mero repetidor da lei, sem qualquer grau ou senso de justiça.

Como há sentidos possíveis dessa norma, os magistrados proferem escolhas a partir da maneira como interpretam, de modo que nem todas as normas são fechadas, possuem esta abertura para a atuação do magistrado em busca do fim social da mesma, bem como da máxima efetividade normativa, em razão dos valores constitucionais.

O julgador não possui o dever da mera exegese do texto de forma mecânica, sem

Constitucionalidade 43, 44 e 54.

${ }^{6}$ Presente em AGOSTINHO, Santo. A Cidade de Deus: (contra os pagãos). Vol. I e II. Tradução de Oscar Paes Leme, Bragança Paulista: Editora Universitária São Francisco, 2003. 
observar a realidade. Pois como definiu o Ministro Luís Roberto Barroso em seu voto: “a realidade é parte da normatividade do direito. Os textos normativos oferecem um ponto de partida para a interpretação, e oferecem os limites possíveis da interpretação", agindo dentro da moldura onde o interprete deve fazer escolhas.

Não é uma discricionariedade, mas sim o dever de realizar a melhor interpretação possível da norma, visando a máxima efetividade e aplicação da lei (BRASILEIRO, 2017, p. 483), não visando as suas próprias preferencias, mas sim realizem a vontade constitucional e consequentemente a vontade do tecido social.

Nessa perspectiva, a Lei de Introdução as Normas do Direito Brasileiro assevera, no artigo $5^{\circ}$, o norte interpretativo em que os julgadores devem se pautar: "na aplicação da lei, o juiz atenderá os fins sociais a que ela se dirige, e as exigências do bem comum”.

Não citando-se a textualidade e literalidade de forma única de interpretação de textos normativos, pois o julgador tornar-se-ia um mero repetidor, mecânico de leis. Em uma sociedade em crescente desenvolvimento tecnológico, poderemos, em um futuro próximo, onde pessoas serão substituídas por máquinas, e quiçá, a magistratura sofra com esse mal. Onde possa produzir um maquinário específico para produzir decisões judiciais, onde seria necessário apenas a leitura do dispositivo legal para cada caso, e pronto, o caso estaria resolvido. Lá será possível uma máquina, através de contas de adição e subtração decidir se um réu é culpado ou não somente com base na lei. Outra ilusão?

Talvez, contudo, não estamos nesse ilusório tempo, e devemos nos atentar à realidade, e a realidade é que um condenado em segundo grau, não possui o direito expresso na Constituição da República, de procrastinar o processo indefinidamente, muito menos desconsiderar uma sentença condenatória e um acórdão prolatado determinando a pena privativa de liberdade.

Pois, colocaria em risco as garantias constitucionais de outros cidadãos, que não foram julgados e condenados em duas instâncias, e sim, ainda, confiam no aparato estatal, para punir aqueles que crimes praticam.

Considerando que, a partir do momento em que os cidadãos entregam ao Estado, o poder de punir, asseverando que as demais garantias com eles permanecerão, e somente abdicarão do "direito de realizar justiça" com as próprias mãos, por uma questão de civilidade, confia-se que tal "contrato social" seja cumprido.

Presume-se que o Estado vá cumprir e realizar a justiça, em casos onde fora provocado a agir. Se o Estado, provocado a agir, por meio do Ministério Público, promove o indiciamento do acusado - o mesmo é submetido as regras do jogo democrático - são 
analisadas as provas, e é julgado e condenado. Evidentemente que terá direito a recorrer da decisão.

Pois, as pessoas erram, ninguém é o senhor absoluto da verdade, possível que um magistrado se equivoque em um momento, e sentencie um réu, em completo descompasso com a lei ou outros mandamentos constitucionais, seja por motivos de sobrecarga de trabalho, tempo ou outros obstáculos que são objetos deste trabalho, e fogem do propósito do mesmo.

Para tanto, possui a garantia de recorrer da sentença, realizando-se posteriormente um julgamento colegiado, onde a falibilidade humana é drasticamente diminuída, tendo em vista a atuação e o sentenciamento em conjunto.

O fato é agravado, quando considerarmos que o percentual de mudança, ou alteração da situação do réu, passados os inúmeros recursos protelatórios ou não, é mínimo.

Ou quando considerarmos que a mudança da jurisprudência com a possibilidade de encarceramento após o julgamento em segundo grau diminui o encarceramento, ao contrário do que possa o senso comum pensar, através de dados oficiais.

O Departamento Penitenciário Nacional através do número de presos preventivos e provisórios, chegando a conclusão de que em 2010, primeiro ano após a proibição do cumprimento de pena depois do julgamento em segundo grau, havia 496.000 presos no sistema penitenciário, aumentando o índice de encarceramento 4,79\%; em 2011 havia 514.600 presos, um aumento de 3,68\%; em 2012, havia 549.800 presos, aumento de 6,84\%; em 2013 havia 581.500 presos, aumento de 5,76\%, em 2014, havia 622.200 presos, aumento de 6,99\%; em 2015, havia 698.600 presos, aumento de 12,27\%; em 2016, havia 722.923, aumento de $3,48 \%$ com relação ao ano anterior ${ }^{7}$.

Em 2016, o Supremo Tribunal Federal após alterar o seu entendimento, a mudança na jurisprudência permitindo a execução da pena após a condenação em segundo grau, permitiu que ao final de 2017, o número de presos no sistema penitenciário de 726.354 presos, com um aumento irrisório de $0,47 \%$, o menor desde então.

No ano de 2018, havia um total de 744.216 presos, um aumento de $2,45 \%$, o segundo menor desde 2009. Portanto, nos dois após a alteração na jurisprudência do Supremo Tribunal Federal, que permitia a prisão logo após o julgamento em segunda instância promoveu a redução no índice de crescimento do encarceramento.

Entre 2009 à 2016, período em fora expressamente proibida o cumprimento da pena anterior ao trânsito em julgado, a média de aumento anual fora de 6,25 \%, e após 2016, com a

\footnotetext{
${ }^{7}$ Disponível em https://www.conjur.com.br/dl/leia-voto-ministro-barroso-execucao.pdf. Acessado em 28 de março de 2020.
} 
alteração na jurisprudência, a média reduziu para $1,46 \%$.

São os dados oficiais do Departamento Penitenciário Nacional, que indicam a redução de menos de um terço no índice de crescimento de encarceramento, contrariando o senso comum, e as raras alegações que a permissão de cumprimento da pena logo após a condenação em segundo grau aumentariam drasticamente o encarceramento.

E como consequência, os tribunais passaram a atuar com maior cautela, e os juízes de primeira instância, ciente da maior efetividade da justiça criminal, passaram a decretar menos prisões provisórias.

Não foram os menos favorecidos economicamente que sofreram com o impacto da proibição de cumprimento de pena logo após a condenação em segunda instância, pois há uma seletividade do sistema, visto que quem poderá arcar com os recursos especiais ou extraordinários serão os criminosos de alto escalão, uma vez que a defensoria pública não atua sob o viés protelatório, e as pessoas menos favorecidas não possuem condição financeira para custear esses infindáveis recursos judiciais.

Houve razões específicas para este overruling $^{8}$ em 2016, como principalmente em razão dos impactos negativos ocasionados pelo determinado entendimento. A alteração na jurisprudência majorou o indicie de encarceramento anual, aumentando drasticamente ano a ano.

Outro impacto negativo é a utilização de mecânicas recursais para postergar o cumprimento da pena, através de recursos meramente protelatórios, carentes de qualquer finalidade de revisão ou reapreciação de determinada questão.

Além do descrédito ao sistema justiça, pela (de)mora na determinação da punição, e pelas frequentes prescrições, gerando a impunidade.

Deve-se, portanto, haver uma profunda reformulação nesse entendimento do Supremo Tribunal Federal e da jurisprudência, passando a admitir a execução provisória da pena. Pois o guardião da constituição, encontra-se completamente perdido nos rumos dados à justiça penal, fulminando em inúmeros recursos meramente protelatórios que adiam o trânsito em julgado.

Apesar do princípio da ampla defesa não ser absoluto, e de não se contemplar o seu

\footnotetext{
${ }^{8}$ Como define o professor Bernardo Gonçalves Fernandes, o entendimento jurisprudencial não deve fossilizar, pois o entendimento sobre determinada matéria hoje, pode ser diferente do observado há cinquenta anos. Sendo o overruling uma técnica que promove uma superação de um precedente. O precedente perde sua força vinculativa, e é substituído por outro precedente, ocorrendo de forma tácita ou implícita, o chamado implied overruling, que ocorre quando não há expressa substituição do posicionamento anterior, não obstante adotese novo posicionamento, em razão da alteração da percepção do direito com relação àquela matéria, alterou a realidade fática ou pelos impactos negativos produzidos por um determinado entendimento jurisprudencial (FERNANDES, 2017, p. 1268).
} 
exercício abusivo, ele tem servido como instrumento a prorrogação da impunidade. Ressalte-se, que o termo impunidade é claramente utilizado neste caso, visto que o réu, fora investigado, processado, condenado em primeira instância, recorreu e fora condenado por órgão colegiado em segunda instância, que decidiu por punir aquele que subverteu à ordem pública praticando um delito - assim, nada mais é do que uma prorrogação da impunidade.

Senão é um trabalho em vão e inútil das instâncias anteriores, onde a regra que Constituição da República quis estabelecer é uma reserva de jurisdição, de que somente o autoridade judiciária poderá prender, de modo que autoriza a prisão temporária, preventiva, para fins de extradição, expulsão e deportação.

Uma vez que o inciso LVI da Constituição da República diz que "ninguém será considerado culpado até o trânsito em julgado de sentença penal condenatória”, ora, diz que ninguém será considerado culpado até o trânsito em julgado, de modo que o artigo que versa sobre a prisão é o inciso LXI, que diz que "ninguém será preso senão em flagrante delito ou por ordem escrita e fundamentada de autoridade judiciária competente, salvo nos casos de transgressão militar ou crime propriamente militar, definidos em lei”, assim o requisito para se decretar a prisão é a ordem escrita e fundamentada da autoridade judiciária competente, e não o trânsito em julgado.

Em diversas questões jurídicas, principalmente criminais, roga-se para que o Brasil acompanhe o restante do mundo, seja nas tendências ou implementações de políticas criminais, por uma questão de civilidade, deve-se adotar o entendimento anterior, possibilitando a execução da pena logo após a condenação em segundo grau. 


\section{CONSIDERAÇÕES FINAIS}

Como visto, as rasas argumentações que defendem pela impossibilidade de cumprimento da pena logo após o julgamento em segunda instância foram superadas, através da análise de dados oficiais do Departamento Penitenciário Nacional, que asseveraram que o índice de crescimento da população carcerária diminui, atingindo a menor proporção histórica, fruto da alteração na jurisprudência sobre o tema em 2016, retomando o posicionamento tradicional.

Demonstrando empiricamente que o cumprimento da pena em segunda instância não agrava o problema do encarceramento.

E como consequência, os tribunais passaram a atuar com maior cautela, de modo que juízes de primeira instância, ciente da maior efetividade da justiça criminal, passaram a decretar menos prisões provisórias.

Visto que o panorama atual promove uma situação calamitosa, que incentiva as prisões provisórias, visto que as proporções de insegurança no cumprimento de pena são alarmantes, e ainda considerados os inúmeros casos em que os recursos protelatórios caminham rumo a prescrição, simultaneamente a ineficiência do sistema promove um escalonamento de prisões provisórias, visto a impossibilidade de execução da pena após o julgamento em segundo grau.

São inúmeras incongruências, dentre elas, frequentemente tem tratado o princípio da presunção de inocência, como regra. De modo claro e evidente, se fosse regra, não seria possível a prisão provisória por exemplo. Deste modo, regras são comando definitivos, ou você cumpre ou descumpre, já os princípios são ideários cumpridos muitas vezes coalizando com outros princípios contrapostos.

As incongruências são colocadas em discussão.

Discussões que em certa medida são salutares ao jogo democrático, o amplo debate de ideias, e as discussões, que são repetidas frequentemente, promovem o não engessamento de posicionamentos judiciais. De modo que, a concepção de que o que temos como "liberdade" hoje, é muito diferente da liberdade de 30 anos atrás e pode ser muito diferente daqui trinta anos.

Porém, é necessária uma estabilização jurisprudencial no que tange a execução da pena após a condenação em segundo grau, definindo solidamente este assunto, desenvolvendo a jurisprudência no caminho à máxima eficácia dos direitos fundamentais dos cidadãos, coadunando-se com o ideário de justiça, presente em nossa sociedade democrática. 


\section{REFERÊNCIAS BIBLIOGRÁFICAS}

ALEXY, Robert. Derecho y Razón Prática. 2 ed. México. Fontamara, 1998.

AGOSTINHO, Santo. A Cidade de Deus: (contra os pagãos). Vol. I e II. Tradução de Oscar Paes Leme, Bragança Paulista: Editora Universitária São Francisco, 2003.

BONAVIDES, Paulo. Curso de Direito Constitucional, 14ª edição, 2003.

BONAVIDES, Paulo. A quinta geração de direitos fundamentais. Revista Brasileira De Direitos Fundamentais \& Justiça, 2008. https://doi.org/10.30899/dfj.v2i3.534.

BRASIL. Constituição (1988). Constituição da República Federativa do Brasil. Brasília, DF: Senado Federal: Centro Gráfico, 1988.

Lei Complementar n. 135, de 4 de junho de 2010. Brasília, DF: Senado Federal: Centro Gráfico, 1988.

Supremo Tribunal Federal. Julgamento ADC 44, 45 e 54. Ministro: Luís Roberto Barroso.

Supremo Tribunal Federal. Habeas Corpus 126.292 São Paulo. Ministro Luiz Fux, p. 58.

Supremo Tribunal Federal. Habeas Corpus 126.292 São Paulo. Relator: Teori Zavascki.

BRASILEIRO, Renato. Código de Processo Penal Comentado. 2. ed. rev. e atual. Salvador: Juspodivm, 2017, p. 483.

BUDÓ, Marília de Nardin; DALLASTA, Karina. In dubio pro societate na progressão de regime: defesa social, periculosidade, vulnerabilidade. Revista Jurídica, [S.1.], v. 3, n. 44, p. 499 - 534, fev. 2017. ISSN 2316-753X. Disponível em: <http://revista.unicuritiba.edu.br/index.php/RevJur/article/view/1878/1248>. Acesso em: 23 abr. 2020. doi:http://dx.doi.org/10.21902/revistajur.2316-753X.v3i44.1878.

CANOTILHO, José Joaquim Gomes. Direito constitucional e teoria da constituição. 7. ed. Coimbra: Almedina, 2002.

FERNANDES, Bernardo Gonçalves. Curso de Direito Constitucional/ Bernardo Gonçalves Fernandes - 9. ed. rev. ampl. e atual. - Salvador. Juspodivm, 2017.

FREUD, Sigmund. O Futuro de Uma Ilusão. In: Edição Standard Brasileira das Obras Psicológicas Completas de Sigmund Freud, Volume 21. O Futuro de uma Ilusão, O Mal Estar na Civilização e outros trabalhos (1927-1931). Rio de Janeiro: Imago, 1996.

MIRANDA, Jorge. Manual de direito constitucional. Tomo li e IV. Ed. Coimbra, 1990.

PACELLI, Eugênio. Curso de processo penal. 21. ed. rev., atual. e ampl. - São Paulo: Atlas, 2017. 